\title{
Assessment of Time Periods of Exogenous Development of Trichostrongylus tenuis Nematodes, Parasitizing in Domestic Goose
}

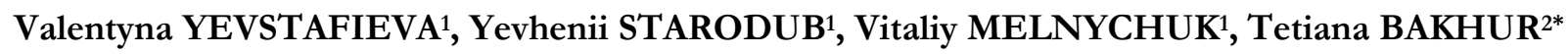 \\ ${ }^{1}$ Poltava State Agrarian Academy, Faculty of Veterinary Medicine, Department of Parasitology and Veterinary-Sanitary \\ Examination, 36003, Poltava, Ukraine \\ ${ }^{2}$ Bila Tserkva National Agrarian University, Faculty of Veterinary Medicine, Department of Parasitology and Pharmacology, \\ 09111, Bila Tserkva, Ukraine
}

\begin{abstract}
The aim of present study was to assess the time periods of exogenous development of Trichostrongylus tenuis nematodes that parasitize in domestic goose, and their survival in vitro. To do that, eggs of Trichostrongylus were obtained from excrement of infected birds and cultured in laboratory to the third stage larvae (L3). Culturing was performed at $15^{\circ} \mathrm{C}, 20^{\circ} \mathrm{C}$ and $25^{\circ} \mathrm{C}$. Time periods of the parasitic development was analyzed, as well as their survival. According to results, the optimum temperature of embryonic and postembryonic development of T.tenuis is $25^{\circ} \mathrm{C}$. The time period of exogenous development at $25^{\circ} \mathrm{C}$ was the shortest (five days), and survival was $83.67 \%$. Decreasing temperature resulted in slower development of infectious larvae (10 days) of lower survival $(58.67 \%)$. Developmental processes in eggs and larvae of Trichostrongylus were accompanied by changes in their sizes regardless of the temperature conditions. Parasitic embryogenesis was characterized by increasing length and width of eggs. Postembryonic development of nematodes was associated with inflating length and width of second stage larvae, but inflating length and decreasing width of third stage larvae.
\end{abstract}

Keywords: domestic goose, trichostrongylosis, exogenous development

\section{Evcil Kazlarda Parazitlenen Trichostrongylus tenuis Nematodların Ekzojen Gelişim Sürelerinin Değerlendirilmesi}

ÖZ

Bu çalışmanın amacı, evcil kazlarda parazitlenen Trichostrongylus tenuis'in eksojen gelişim ve in vitro ortamda canlı kalma sürelerini değerlendirmektir. Enfekte kuşların dışkısından izole edilen Trichostrongylus spp. yumurtaları laboratuvar ortamında 3. dönem larva elde edilmek üzere $15^{\circ} \mathrm{C}, 20^{\circ} \mathrm{C}$ ve $25^{\circ} \mathrm{C}$ olmak üzere üç farklı sicaklıkta kültür edilmiştir. Farklı sıcaklıklardaki larva gelişimi ve canlı kalma süreleri analiz edilmiştir. Elde edilen analiz sonuçlarına göre, T. tenuis' in embriyonik ve postembriyonik gelişimi için optimum sıcaklık $25^{\circ} \mathrm{C}$ ' dir. Larvalar, in vitro ortamda en hızlı gelişimi 5 günde $25^{\circ} \mathrm{C}$ 'de göstermişler ve $\% 83.67$ hayatta kalmışlardır. Azalan sıcaklık, enfektif larvaların daha yavaş gelişimine (10 gün) ve daha kısa süre canlı kalmalarına (\% 58.67) sebep olmuştur. Trichostrongylus yumurta ve larvaları her üç sıcaklık ortamında, farklı değerlerde olsa da gelişim göstermiştir. Parazitik embriyogenez, yumurtaların uzunluğunun ve genişliğinin artması ile karakterize edilmiştir. Nematodların postembriyonik gelişimi sırasında, ikinci dönem larvalarda uzunluk ve genişlikte artış gözlenirken, üçüncü dönem larvalarda uzunlukta artış, genişlikte ise azalma gözlemlenmiştir.

Anahtar Kelimeler: Kaz, trichostrongylosis, ekzojen gelişim

To cite this article: Yevstafieva V. Starodub Y. Melmychuk V. Bakbur T. Assessment of Time Periods of Exogenous Development of Trichostrongylus tenuis Nematodes, Parasitizing in Domestic Goose. Kocatepe Vet J. (2020) 13(3):228-233

Submission: 15.04 .2020

Accepted: 03.06.2020

Published Online: 18.06 .2020

ORCID ID; VY: 0000-0003-4809-2584, YS: 0000-0002-7880-8283, VM: 0000-0003-1927-1065, TB: 0000-0001-8271-8267

*Corresponding author e-mail: fly_13@ukr.net 


\section{INTRODUCTION}

The poultry farming may develop not only by creating new highly productive breeds of geese, improving diets for nutrients, but by also ensuring sustainable epizootic control (Romanov 1999, Elmberg et al. 2017). The common helminth infections of geese include gastrointestinal nematodoses. One of the most widespread gastrointestinal nematodoses is trichostrongyloidosis, associated with significant losses for poultry farming (Enigk and Dey-Hazra 1971, Shutler et al. 2012).

Epizootological features of trichostrongyloidosis have been mostly studied in wild birds (Anseriformes, Galliformes, Gruiformes, and Otidiformes), and this infection is widespread throughout Europe, Asia, North America, Africa, Australia, New Guinea, New Zealand. There, the infection rates can reach $100 \%$, and the intensity of infection can be up to 2471 nematode specimens per bird (Calvete et al. 2003, Webster et al. 2007, Bhat et al. 2014).

Most of the scientific works are studies of the parasitization of Trichostrongylus tenuis in partridges. The pathogen destabilizes the dynamics of partridge population, leading to its decline. Moreover, the prevalence of infection in partridges reaches $90 \%$, the intensity of infection is up to 30.000 nematode specimens, and infection rates are higher (in 30 times) in adult birds than in young animals (Wilson 1983, Fox and Hudson 2001, Newborn and Foster 2002, Seivwright et al. 2004).

It has been proven that $T$. tenuis nematodes evolved from the free-living ancestors of modern rhabditates. This is indicated by their partial free-living lifestyle, namely the part of the life cycle and metamorphoses that occur outside the host's body, in the external environment. The parasite's development is direct involving one definitive host. The wild birds and poultry that are susceptible to the causative agent of trichostrongyloidosis include Anser albifrons, Anser anser dom., Gallus gallus dom., Anas platyrbynchos dom., Meleagris gallopavo, Anas platyrbynchos, Branta canadensis, Chen caerulescens, Lagopus scoticus, Lagopus muta, Numida meleagris, Otis tarda, Perdix perdix, Pavo cristatus, Phasianus colcbicus. Moreover, such a wide distribution of this pathogen in birds is explained by the peculiarities of its development, where exogenous preservation of the parasite at the stages of the egg and larva allows parasites to survive as a species (Watson et al. 1988, Cattadori et al. 2005, Skírnisson et al. 2012).

Thus, a comprehensive study of Trichostrongylus tenuis parasites of domestic goose is not only of general biological interest, but it has a great importance in the ensuring of trichostrongylosis epizootic control at poultry farms also.

\section{MATERIAL and METHODS}

Studies were conducted at the Laboratory of the Parasitology and Veterinary Expertise of the Department of Veterinary Medicine of the Poltava State Agrarian Academy (Poltava, Ukraine, $49^{\circ} 35^{\prime} 42$ " N $34^{\circ} 33^{\prime} 19$ " E) in 2019.

The time periods of the exogenous development of T. tenuis nematodes were studied in laboratory conditions. In order to do that, helminth eggs were isolated using Kotelnikov-Khrenov's method of coproscopic examination of domestic goose reared in private farms of Poltava region (Kotelnikov, 1984), from excrement of infected birds. The obtained washed eggs were transferred to Petri dishes, $100 \pm 5$ eggs per dish, and cultured in a thermostat at various temperatures $\left(15^{\circ} \mathrm{C}, 20^{\circ} \mathrm{C}\right.$ and $\left.25^{\circ} \mathrm{C}\right)$ until the formation of third stage larvae (L3). Samples were examined daily under a microscope. The stage of development of eggs and larvae of nematodes was determined by morphological structure, considering the timing of their development and taking into account the number of dead eggs and larvae. Each experiment was carried out in triplicate.

The metric parameters of T.tenuis eggs and larvae during their development were studied using ImageJ for Windows ${ }^{\circledR}$ software (version 2.00). Microphotography was performed using a digital camera to a MikroMed 5Mpix microscope (China).

The research protocol of the current study was approved by the Ethic Committee of the Poltava State Agrarian Academy (Approval number: 2019/02).

\section{Statistical analysis}

Statistical processing of the experimental results was carried out using Statistica 10 (StatSoft Inc., USA) software. Standard deviation (SD) and average values (M) were calculated. Significance of difference between average values in studied eggs and larvae cultures of T. tenuis was established using one-way analysis of variance and F-test. The statistically significant rate was set as $\mathrm{p}<0.05$.

\section{RESULTS}

The exogenous development of T. tenuis was shown to include five stages: blastomere cleavage (Fig. 1 a), larval formation in egg (embryonic) (Fig. 1 b), and postembryonic formation of first stage (L1) (Fig. 1 c), second stage (L2) (Fig. $1 \mathrm{~d}$ ) and third stage (L3) larva (Fig. 1 e). The timing of development and survival rates of exogenous stages of parasites depended on the temperature regime (Table 1). 
The most optimal temperature for the successful development of eggs to the infectious L3 was $25^{\circ} \mathrm{C}$. The time periods of development were the shortest, five days at this temperature, and the survival rate was $83.67 \pm 3.51 \%$. A decrease in temperature contributed to longer development of Trichostrongylus, and nematode survival was reduced to $75.33 \pm 1.53 \%$ at $20^{\circ} \mathrm{C}$ and to $58.67 \pm 2.08 \%$ at $25^{\circ} \mathrm{C}$.

The morphometric parameters of T.tenuis eggs were studied during their embryonic development. Regardless of the temperature of cultivation, their length and width changed (Table 2).

At $15^{\circ} \mathrm{C}$, the length and width of Trichostrongylus eggs increased by $3.77 \%(\mathrm{p}<0.01)$ and $6.39 \%(\mathrm{p}<0.001)$, respectively. At $20^{\circ} \mathrm{C}$, the parameters of eggs during cultivation significantly $(\mathrm{p}<0.001)$ increased: length by $4.62 \%$, width by $8.08 \%$. Cultivation at $25^{\circ} \mathrm{C}$ also led to an increase in their size $(p<0.001)$ : length by $5.44 \%$, width by $7.82 \%$. During postembryonic development of T.tenuis larvae, their sizes changed at all temperature conditions (Table 3).

At $15^{\circ} \mathrm{C}$, the length and width of the second stage larvae (L2) increased relative to the sizes of the first stage larvae (L1) by 22.10 and $8.55 \% \quad(\mathrm{p}<0.001)$, respectively. Similar data were obtained for cultivation at $20^{\circ} \mathrm{C}$ and $25^{\circ} \mathrm{C}$. The length of $\mathrm{L} 2$ increased by 22.21 and $20.26 \%(\mathrm{p}<0.001)$, and the width increased by 8.26 and $8.72 \%(\mathrm{p}<0.001)$. At the same time, infectious larvae of the third stage (L3) had a longer and narrower body in comparison with L1. At $15^{\circ} \mathrm{C}$, length of L3 increased by $26.74 \%$ $(p<0.001)$, and the width decreased by $5.20 \%$ $(\mathrm{p}<0.01)$. At $20^{\circ} \mathrm{C}$, L3 were longer (by $26.34 \%$, $\mathrm{p}<0.001$ ) and narrower (by 7.88\%, $\mathrm{p}<0.001$ ). The same tendency in L3 body size changes during postembryonic development was also observed at $25^{\circ} \mathrm{C}$. Infectious larvae were longer by $24.27 \%$ $(\mathrm{p}<0.001)$ and narrower by $11.60 \%(\mathrm{p}<0.001)$ relative to L1.

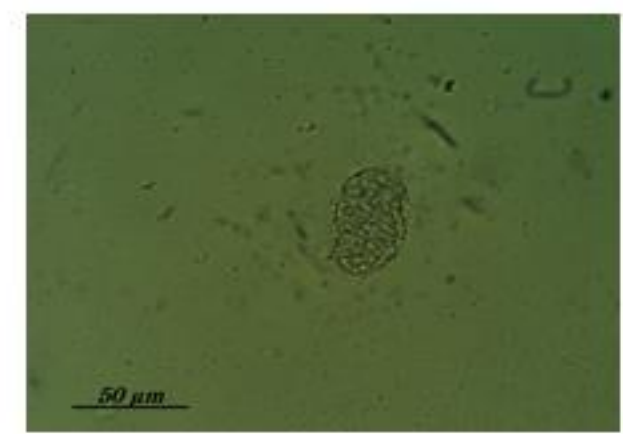

a

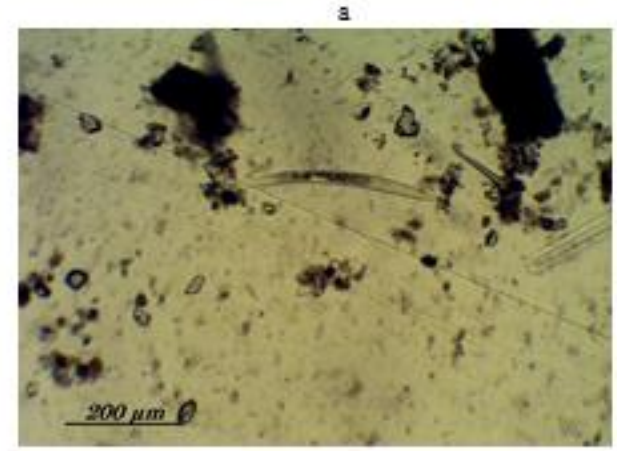

c

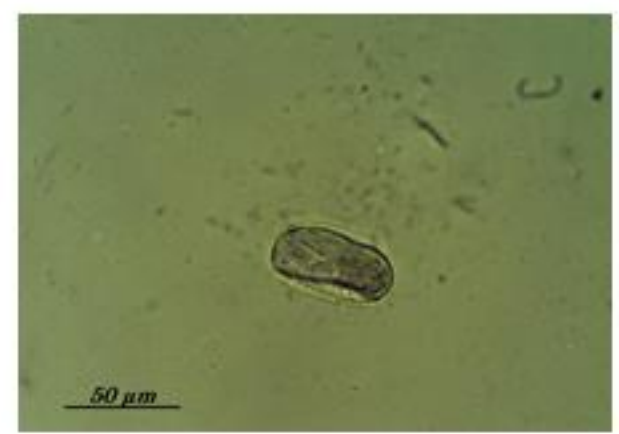

b

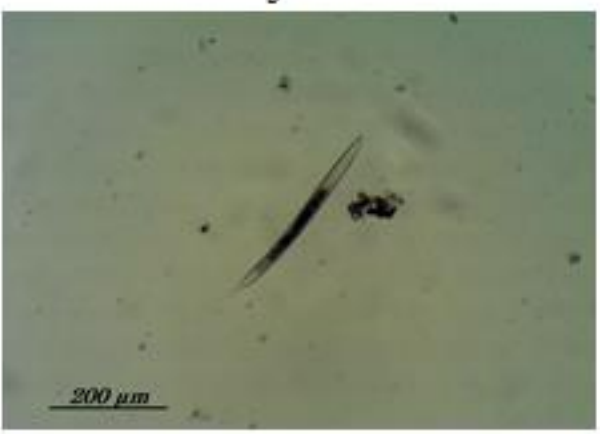

d

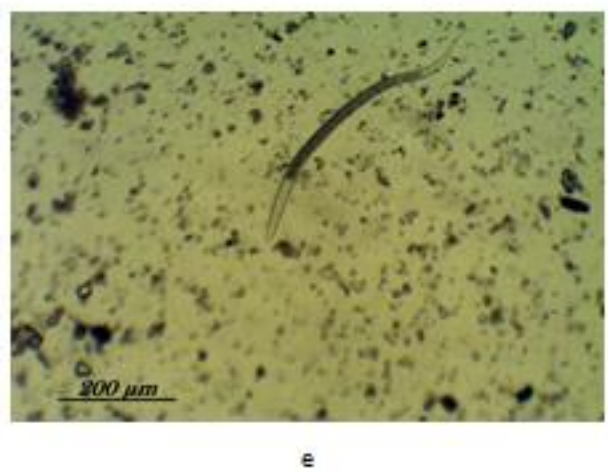

Fig. 1. Stages of embryonic and postembryonic development of nematodes Trichostrongylus tenuis, which parasitize domestic geese: $\mathrm{a}$ - blastomere cleavage; $\mathrm{b}$ - formation of larvae in the egg; $\mathrm{c}-$ L1; d - L2; e - L3 
Table 1. The effect of temperature on the timing of exogenous development and survival of Trichostrongylus tenuis in laboratory culture, $\mathrm{n}=100, \mathrm{M} \pm \mathrm{SD}$

\begin{tabular}{ccc}
\hline Temperature $\left({ }^{\mathbf{0}} \mathbf{C}\right)$ & Duration of development (days) & Rates of formation of L3 (\%) \\
\hline 15 & 10 & $58.67 \pm 2.08$ \\
20 & 7 & $75.33 \pm 1.53$ \\
25 & 5 & $83.67 \pm 3.51$ \\
\hline
\end{tabular}

Table 2. Morphometric parameters of Trichostrongylus tenuis eggs during embryonic development, $\mathrm{n}=10, \mathrm{M} \pm \mathrm{SD}$

\begin{tabular}{lccc}
\hline \multirow{2}{*}{$\begin{array}{c}\text { Parameters } \\
(\mu \mathrm{m})\end{array}$} & $\begin{array}{c}\text { Temperature } \\
\left({ }^{0} \mathbf{C}\right)\end{array}$ & Blastomere cleavage & Formation of larva in egg \\
\cline { 3 - 4 } & 15 & $69.21 \pm 1.56$ & $71.92 \pm 1.93^{* *}$ \\
Len/gth & 20 & $69.03 \pm 1.29$ & $72.37 \pm 1.85^{* * *}$ \\
& 25 & $68.82 \pm 1.51$ & $72.78 \pm 1.60^{* * *}$ \\
\hline \multirow{3}{*}{ Width } & 15 & $37.23 \pm 1.15$ & $39.77 \pm 1.69^{* * *}$ \\
& 20 & $37.19 \pm 1.36$ & $40.46 \pm 0.95^{* * *}$ \\
& 25 & $37.74 \pm 1.28$ & $40.94 \pm 1.15^{* * *}$ \\
\hline
\end{tabular}

Note: ${ }^{* *}-\mathrm{p}<0.01 ; * * *-\mathrm{p}<0.001-$ compared to values for eggs at the stage of blastomere cleavage

Table 3. Morphometric parameters of Trichostrongylus tenuis larvae during postembryonic development, $\mathrm{n}=10$, $\mathrm{M} \pm \mathrm{SD}$

\begin{tabular}{ccccc}
\hline \multirow{2}{*}{ Larval stages } & Parameters, & \multicolumn{3}{c}{ Temperature $\left.\mathbf{(}^{\circ} \mathbf{C}\right)$} \\
\cline { 3 - 5 } & $\boldsymbol{\mu m}$ & $\mathbf{1 5}$ & $\mathbf{2 0}$ & $\mathbf{2 5}$ \\
\hline \multirow{2}{*}{ L1 } & Length & $367.55 \pm 17.44$ & $372.46 \pm 13.44$ & $385.19 \pm 15.66$ \\
& Width & $23.65 \pm 0.57$ & $23.99 \pm 0.48$ & $24.39 \pm 0.68$ \\
\hline \multirow{2}{*}{ L2 } & Length & $471.84 \pm 6.87^{* * *}$ & $478.81 \pm 6.02^{* * * *}$ & $483.04 \pm 5.74^{* * *}$ \\
& Width & $25.86 \pm 0.70^{* * *}$ & $26.15 \pm 0.71^{* * *}$ & $26.72 \pm 0.62^{* * *}$ \\
\hline \multirow{2}{*}{ L3 } & Length & $501.70 \pm 2.89^{* * *}$ & $505.63 \pm 3.33^{* * *}$ & $508.65 \pm 4.90^{* * *}$ \\
& Width & $22.42 \pm 1.06^{* *}$ & $22.10 \pm 1.32^{* * *}$ & $21.56 \pm 1.28^{* * *}$ \\
\hline
\end{tabular}

Note: ${ }^{* *}-\mathrm{p}<0.01 ; * * *-\mathrm{p}<0.001-$ compared to values for first stage larvae (L1)

\section{DISCUSSION}

According to scientific evidence, trichostrongyloidosis is a significantly common disease of birds, both wild and domestic. Its pathogens are nematodes of the species Trichostrongylus tenuis. The disease occurs in both waterfowl and terrestrial birds in many countries of the world (Wascher et al. 2012, Cervantes-Rivera et al. 2016, Denizhan and Karakuş 2019). The high prevalence of pathogen in various bird species is explained by the biological specifics of T.tenuis that enhance its adaptation to environmental factors, which affect the exogenous development of the parasite (Dobson and Hudson 1992, Connan and Wise 1993). Thus, further studies are needed to determine the timing of the development of these nematodes in the external environment and the influence of temperature on the rate of L3 formation and survival. This will allow to use the correct and more effective preventive and therapeutic anthelmintic measures in poultry farming.

We found that the temperature factor significantly affects the timing of exogenous development of T.tenuis nematodes, and is also one of the factors determining their survival. The most favorable temperature for the formation of the largest number of infectious larvae (up to $83.67 \pm 3.51 \%$ ) under laboratory conditions is $25^{\circ} \mathrm{C}$. In these conditions, the exogenous development of $T$. tenuis occurs in five days. With decreasing temperature, the formation of 
L3 slows down to seven days at $20^{\circ} \mathrm{C}$, or 10 days at $15^{\circ} \mathrm{C}$. At the same time, the survival of L3 decreases to $75.33 \pm 1.53 \%$ at $20^{\circ} \mathrm{C}$, or $58.67 \pm 2.08 \%$ at $15^{\circ} \mathrm{C}$. Such dependence of the development time and survival of T.tenuis on temperature both in the laboratory and in the environment has been noted before (Shaw et al. 1989). The authors indicate that eggs do not develop to L3 and die at low temperatures of winter, while mass formation of infectious larvae occurs in summer, at an average monthly soil surface temperature of 7.6 to $10.3^{\circ} \mathrm{C}$. At the same time, it has been observed that temperature indirectly affects the development of infectious larvae. A colder temperature $\left(10^{\circ} \mathrm{C}\right)$ provides better humidity conditions on the surface of the vegetation for migration of larvae (Saunders et al. 2000).

We also obtained new data on the morphometric parameters of T.tenuis during exogenous development. The embryonic development is characterized by an elongation (by 3.77-5.44\%) and widening (by $6.39-8.08 \%$ ) of eggs. In the process of postembryonic larval development, we noted an increase in L2 in length (by 20.26-22.21\%) and width (by $8.26-8.72 \%$ ), and further in L3, an increase in their length (by $24.27-26.74 \%$ ) with a decrease in width (by $5.20-11.60 \%$ ). Such changes, in our opinion, contribute to maximum survival in the external environment, and the possibilities of migration on plants for further entry into the host organism.

\section{CONCLUSION}

The timing of exogenous development and survival are determined in different temperature conditions for Trichostrongylus tenuis nematodes isolated from domestic geese. It is established that the optimal temperature for the formation of infectious larvae is $25^{\circ} \mathrm{C}$, at which their formation occurs in five days, and survival reaches $83.67 \%$. The growth and development of exogenous parasitic stages is accompanied by a change in their morphometric characteristics. That is an adaptive mechanism to environmental conditions, which contributes to the widespread occurrence of trichostrongyloidosis in birds.

Conflict of Interest: The authors declare that they have no conflict of interest.

\section{REFERENCES}

Bhat SA, Khajuria JK, Katoch R, Wani MY, Dhama K. Prevalence of Endoparasites in Backyard Poultry in North Indian Region: A Performance Based Assessment Study. Asian J. Anim. Vet. Adv. 2014; 9: 479-488.

Calvete C, Estrada R, Lucientes J, Estrada A, Telletxea I. Correlates of helminth community in the red-legged partridge (Alectoris rufa L.) in Spain. J. Parasitol. 2003; 89(3): 445-451.

Cattadori IM, Haydon DT, Hudson PJ. Parasites and climate synchronize red grouse populations. Nature. 2005; 433: 737-741.

Cervantes-Rivera K, Villagómez-Cortés JA, Arroyo-Lara A, Landín-Grandvallet LA. A diagnostic survey of gastroenteric helminths in backyard poultry of a rural village in Mexican tropics. J. Agricul. Biol. Sci. 2016; 11(12): 463-469.

Connan RM, Wise DR. Development and survival at low temperature of the free living stages of Trichostrongylus tenuis. Res. Vet. Sci. 1993; 55(1): 20-24.

Denizhan V. Karakuş A. The Prevalence of Gastrointestinal Helminths in Domestically Farmed Chicken in Van, Turkey. Kocatepe Vet. J. 2019; 12(4): 443-447.

Dobson AP, Hudson PJ. Regulation and stability of a free-living host-parasite system: Trichostrongylus tenuis in red grouse. II. Population models. J. Anim. Ecol. 1992; 61(2): $487-$ 498.

Elmberg J, Berg C, Lerner H, Waldenström J, Hessel R. Potential disease transmission from wild geese and swans to livestock, poultry and humans: a review of the scientific literature from a One Health perspective. Infect. Ecol. Epidemiol. 2017; 7(1): 1300450.

Enigk K, Dey-Hazra A. Propagation and treatment of the Trichostrongylus tenuis infestations. Berl. Münch. Tierärztl. 1971; 84(1): 11-14.

Fox A, Hudson PJ. Parasites reduce territorial behaviour in red grouse (Lagopus lagopus scoticus). Ecol. Lett. 2001; 4: 139143.

Kotelnikov GA Diagnostics of animal helminthoses. Koloss, Moscow. 1974; p. 240-241 (In Russian).

Newborn D, Foster R. Control of parasite burdens in wild red grouse Lagopus lagopus scoticus through the indirect application of anthelmintics. J. Appl. Ecol. 2002; 39: 909914.

Romanov MN. Goose production efficiency as influenced by genotype, nutrition and production systems. World Poultry Sci. J. 1999; 55(3): 281-294.

Saunders LM, Tompkins DM, Hudson PJ. Spatial aggregation and temporal migration of free-living stages of the parasitic nematode Trichostrongylus tenuis. Funct. Ecol. 2000; 14: 468-473.

Seivwright LJ, Redpath SM, Mougeot F, Watt L, Hudson PJ. Faecal egg counts provide a reliable measure of Trichostrongylus tenuis intensities in free-living red grouse Lagopus lagpus scoticus. J. Helminthol. 2004; 78: 69-76.

Shaw JL, Moss R, Pike AW. Development and survival of the free-living stages of Trichostrongylus tenuis, a caecal parasite of red grouse Lagopus lagopus scoticus. Parasitology. 1989; 99(1): 105-113.

Shutler D, Alisauskas RT, Daniel McLaughlin J. Associations between body composition and helminths of lesser snow geese during winter and spring migration. Int. J. Parasitol. 2012; 42(8): 755-760.

Skírnisson K, Thorarinsdottir STh, Nielsen OK. The Parasite Fauna of Rock Ptarmigan (Lagopus muta) in Iceland: Prevalence, Intensity, and Distribution Within the Host Population. Comp. Parasitol. 2012; 79(1): 44-55.

Wascher CAF, Bauer AC, Holtmann AR, Kotrschal K. Environmental and social factors affecting the excretion 
of intestinal parasite eggs in graylag geese. Behav. Ecol. 2012; 23(6): 1276-1283.

Watson H, Lee DL, Hudson PJ. Primary and secondary infections of the domestic chicken with Trichostrongylus tenuis (Nematoda), a parasite of red grouse, with observations on the effect on the caecal mucosa. Parasitol. 1988; 97: 89-99.

Webster LMI, Johnson PCD, Adam A, Mable BK, Keller LF. Macrogeographic populations structure in a parasitic nematode with avian hosts. Vet. Parasitol. 2007; 144: 93103.

Wilson GR. The prevalence of caecal threadworms (Trichostrongylus tenuis) in red grouse (Lagopus lagopus scoticus). Oecologia. 1983; 58: 265-268. 